Finance and Economics Discussion Series Divisions of Research \& Statistics and Monetary Affairs Federal Reserve Board, Washington, D.C.

\title{
Are Firms or Workers Behind the Shift Away from DB Pension Plans?
}

\section{Stephanie Aaronson and Julia Coronado}

2005-17

NOTE: Staff working papers in the Finance and Economics Discussion Series (FEDS) are preliminary materials circulated to stimulate discussion and critical comment. The analysis and conclusions set forth are those of the authors and do not indicate concurrence by other members of the research staff or the Board of Governors. References in publications to the Finance and Economics Discussion Series (other than acknowledgement) should be cleared with the author(s) to protect the tentative character of these papers. 


\title{
Are Firms or Workers Behind the Shift Away from DB Pension Plans?
}

\author{
Stephanie Aaronson \\ Federal Reserve Board of Governors \\ Washington DC, 20551 \\ Stephanie.R.Aaronson@frb.gov
}

\author{
Julia Coronado \\ Watson Wyatt Worldwide \\ 1717 H St, NW \\ Washington, DC 20006 \\ Julia.Coronado@watsonwyatt.com
}

February, 2005

\begin{abstract}
One of the most striking changes in the composition of household retirement savings over the past 20 years has been the shift from defined benefit to defined contribution pension plans. Understanding the factors underlying this shift is important for determining its impact on retirement saving adequacy. Yet previous research, which has mostly focused on factors affecting all firms, such as regulation or increased longevity, has yielded little consensus. In this study we estimate the contribution of changing workforce characteristics and production environments to the shift in pension coverage. Our findings suggest that, while aggregate factors explain a large part of the movement, changes in worker demand, due to evolving workforce characteristics, also contributed notably. On the supply side, we find support for the theory that technical change has reduced the value of DB plans. These supply and demand factors are particularly important for explaining the significant variation in cross-industry trends in pension coverage.
\end{abstract}

JEL CLASSIFICATION: J32, J41, J26

The authors wish to thank Daniel Cooper for excellent research assistance, and David McCarthy of the Department of Labor and Steve Rosenthal of the Bureau of Labor Statistics for providing data. Peter Brady, Courtney Coile, Bill English, Richard Hinz, Richard Ippolito, Nellie Liang, Steve Oliner, Michael Palumbo, Wayne Passmore, Syl Schieber, and Bill Wascher provided valuable comments and insights. The views expressed herein are those of the authors and not those of the Federal Reserve Board of Governors or Watson Wyatt Worldwide. 


\section{Introduction}

One of the most striking changes in the composition of household retirement savings over the past 20 years has been the shift from defined benefit to defined contribution pension plans. Between 1979 and 1998 there was a 17 percentage point decline in the proportion of employees covered by traditional defined benefit (DB) pensions and a 12 percentage point rise in the share of employees covered by defined contribution (DC) plans. DB and DC plans are fundamentally different forms of retirement saving, so this switch may have important implications for retirement security. Although there are many differences between the two types of pensions, the most important trade-off is as follows. Participants in defined benefit plans bear little financial market risk as benefits are based on tenure and salary. However, benefit accrual in DB plans is back-loaded, which is to say that participants accrue very little in the way of retirement wealth until the years immediately preceding retirement. Consequently workers who leave jobs in the early and even middle stages of their careers earn few benefits, while those who leave before vesting---generally at 5 years---receive nothing. As a result, job change poses a significant risk to retirement saving for workers covered by DB plans. In contrast, participants in defined contribution plans bear all the investment risk as benefits accrue through annual contributions to individual accounts that are invested in financial markets. But, benefits accrue more evenly over a career and vesting periods are generally a year or less, so there is less risk to retirement wealth accumulation should an individual switch jobs. Taken together, the change in the structure of pension coverage implies that households now face a very different mix of risks in the accumulation of retirement wealth.

Because of the potential implications for retirement security, understanding the shift in pension coverage is essential. A number of explanations have been offered in the economics literature. Many of the most common hypotheses concern changes in factors affecting all firms, for instance changes in the regulatory environment that have raised the cost of sponsoring DB plans and increases in worker longevity. Other hypotheses concern factors affecting a firm's willingness to supply DB pension plans, such as changes in production processes that have reduced the value of the long-term employment relations thought to be promoted by DB plans. A final set of explanations, which has received less attention in the literature, involves factors affecting worker demand for pensions, such as changes in the demographic composition of the workforce. In particular, the rise in the share of women in the workforce in recent decades has 
resulted in an increased number of workers with the primary responsibility for dependents and increased numbers of workers making joint job location decisions. Both of these phenomena may have resulted in workers with weaker attachment to specific employers and greater demand for more portable pensions.

In this study, we quantify the relative importance of these supply and demand factors in explaining the trends in DB and DC pension coverage. The data on pension coverage and workforce characteristics are drawn from the May supplement to the 1979 Current Population Survey (CPS) and the pension supplement to the 1996 Survey of Income and Program Participation (SIPP), administered in 1998. We also merge in additional data on the production environment. Since we cannot follow individual workers or firms over time, we exploit the considerable variation in the provision of DC and DB pensions across 2-digit industries, estimating equations on the determinants of the change in DB or DC coverage for these industries using Seemingly Unrelated Regression (SUR). Because we observe only equilibrium pension coverage, rather than firm supply and individual demand, our equations are reduced form. Nonetheless, with certain identifying assumptions, we can draw conclusions about the supply and demand factors affecting the shifts in pension coverage in equilibrium.

Our findings suggest that shifts in worker demand, due to changes in workforce characteristics, explain a large part of the overall shift in pension coverage. On the supply side, we find support for the theory that changes in technology have reduced the value of DB plans. These demand and supply factors are particularly important in explaining the significant crossindustry variation in pension coverage changes. Factors affecting all firms---such as regulatory issues or increasing longevity---also play an important role in explaining the shift away from traditional DB pensions. Although we cannot separately identify these aggregate factors, they appear to explain a significant amount of the total decline in DB pension coverage, but none of the variation across industries. These results are robust to a specification that accounts for the potential problems of omitted variable bias and endogeneity through the use of instrumental variables.

\section{Background}

As shown in Figure 1, the share of full-time workers that participated in any pension plan (the height of the bars) edged down slightly from around 55 percent in 1979 to less than 50 
percent in 1998. However the composition of pension coverage changed dramatically. The shaded portion of the bars shows that, while two-thirds of workers with pension coverage in 1979 had a DB plan, only a third had a DB plan in 1998. Table 1 shows the fraction of the entire private workforce (both full-time and part-time) covered by a DB or DC pension plan in 1979, the percentage point decline in DB coverage between 1979 and 1998, and the percentage point increase in DC pension coverage for 2-digit SIC industries. Individuals in this table are counted once for each plan they have. While the overall shift in the type of pension coverage was striking, the changes varied considerably across industries. Industries are ranked according to the size of their decline in DB coverage, which ranged from reductions of 39 to 1 percentage points. Correspondingly changes in DC coverage ranged from a decline of more than 8 percentage points to an increase of 38 percentage points.

The fact that all industries moved away from DB coverage is an indication that factors affecting all industries have been at play. However, the tremendous variation in the decline in DB coverage suggests that economic factors that differ across industries have also influenced this shift. Moreover, in many but not all industries, the decline in DB coverage has been closely matched by an increase in DC coverage implying some substitution, although not one for one. ${ }^{1}$ This substitution could be with in a firm or as a result of existing firms with DB plans going out of business and new firms choosing to sponsor only DC coverage. This also suggests that industry-specific conditions have played a role in the evolution of pension coverage.

In order to understand why DC plans have increased in prevalence while DB plans have declined, it is useful to outline the fundamental differences between DB and DC pensions. It is also relevant to keep in mind that DB plans were the first form of employer-sponsored pension, and that DC plans have grown in prominence more recently. Thus, we might frame the comparison by asking which features of traditional pensions DC plans retain and which they eschew. Both DB and DC plans offer employees the opportunity to earn tax-favored returns on their saving and to realize economies of scale on the transaction costs of investment, and both types of pensions offer a convenient commitment mechanism for saving. ${ }^{2}$

1 Using data from the form 5500, Papke (1999) finds considerable evidence of substitution of DC for DB plans within firms.

2 If individuals suffer from lack of self-control, they may appreciate either a DB or DC pension as a commitment mechanism (Laibson, Repetto, and Tobacman, 1998). 
One of the key differences between traditional DB and DC pensions is the very different patterns of benefit accrual over a career. In DB plans employees accrue few benefits early in their careers (and in fact are thought to be paid less than their marginal product) and then realize rapid benefit accrual in the years just prior to retirement. The most common explanation for the existence of these plans is that they allow firms to increase tenure, encourage work effort, and regulate retirement behavior thus boosting overall productivity. ${ }^{3}$ In order to induce employees to accept these terms, it has been suggested that firms share the resulting productivity gains with employees, resulting in higher lifetime compensation than in jobs without such plans (Lazear, 1979). In contrast, DC benefits accrue more evenly as a fraction of salary over a working life and are more portable across employers, having vesting periods of a year or less. As such these plans do not promote long-term relationships. However, participants in traditional DB plan face significant risk to the accumulation of retirement wealth from job change or firm bankruptcy that is largely mitigated in a DC pension. ${ }^{4}$

Another key difference between DC and DB pensions is the allocation of financial market risk. In traditional DB pensions employers typically bear the risk during both the accrual and payout phases, whereas in DC plans employees generally bear this risk. The transfer of risk may in part be a function of the portability of DC pensions; it is difficult to design a portable benefit that does not transfer risk to employees. ${ }^{5}$

To make our ideas concrete, we outline some equilibrium conditions in a market in which firms offering traditional DB pensions compete for workers with firms offering DC pensions. We assume that defined contribution pension accruals are equivalent to cash compensation and that firms that offer such plans operate in a spot market for labor in which workers are paid their marginal product in each time period. Specifically

$$
W_{i t}^{D C}=A_{i}^{D C}+\mathbf{X}_{i t}^{\prime} \boldsymbol{\beta}
$$

3 Analyses of the role of DB pensions in the labor market can be found in Lazear (1979), Hutchens (1989), Mitchell (1990), Gustman, Mitchell, and Steinmeier (1994), Even and MacPherson (1996, 2001) and Friedberg and Owyang (2002).

4 While benefits accrued in private DB pensions are insured by the Pension Benefit Guaranty Corporation in the event of firm bankruptcy, the back-loaded pattern of benefit accrual implies that bankruptcy still poses a risk to retirement wealth accumulation for pre-retirees.

5 For instance with a cash balance plan, another type of portable pension, firms bear the investment risk during a worker's employment. However, a worker who changes jobs receives a payout, for which she then assumes the financial market risk. 
where $W^{D C}$ are wages, including employer contributions to the DC pension. Wages are equal to the worker's marginal product which includes a match-specific productivity component, $A^{D C}$, which depends on the fact that the job has a defined contribution plan, and the return to a vector of observable characteristics $\mathbf{X}$.

We model compensation at a job with a DB plan using a Lazear-type model, in which workers make less than their marginal product in early years but then are paid more than their marginal product when old. In our case they receive a lump-sum pension at retirement. If workers leave the firm prior to retirement, they forgo the pension. This assumption is an extreme version of the delayed accrual and lack of portability associated with a DB plan, but easily illustrates the most salient differences with DC plans.

In evaluating such a compensation scheme, workers will take into account the probability of separation from the firm. In equation form, the expected value of the pension plan over an individual's life is

$$
\sum_{t=1}^{T-1} s_{i t} W_{i t}^{D B}+S_{i} P_{i}^{T} \leq \sum_{t=1}^{T-1}\left(A_{i}^{D B}+\mathbf{X}_{i t}^{\prime} \boldsymbol{\beta}\right)
$$

where $W_{i t}^{D B}$ is the wage paid in period $t$, given that the person is in a job with a pension, and $s_{i t}$ is the independent probability that the worker will still be employed by the firm at time $t$. The lump-sum value of the pension is denoted by $P$ and is paid in period $T$ when the individual retires. To derive the expected value of the pension, the worker weights the pension by $S_{i}$, which is the probability that the worker will be with the firm at retirement and is calculated as the product of the independent probabilities in each period of their tenure. The expected total compensation of the worker is no more than the sum of their marginal product in each period, which is defined analogously to the DC case. ${ }^{6}$

Over their lifetimes, for an individual to choose a job with a traditional DB pension over the job with a DC plan, he or she must be at least indifferent between their expected total compensation in each job. Specifically

$$
\sum_{i=1}^{T-1} S_{i t} W_{i t}^{D B}+S_{i}^{T} P_{i}^{T} \geq \sum_{t=1}^{T-1} W_{i t}^{D C}
$$

6 Our notation assumes that firms pay the same price for characteristics regardless of whether they offer a DB or DC pension. This assumption is made for notational simplicity and has no bearing on the basic insights of the model. 
Compensation in a job with a DC plan is not weighted by probabilities of staying with the firm in the job with a DC plan because we assume that an individual can always find employment in the spot market earning his or her marginal product. Because employees must be compensated for the risk of job change imposed on them by the DB compensation scheme, equation 3 implies that in the event the employee stays with the firm until retirement, their total compensation will be strictly greater than in the job with the DC plan. This premium is paid for through the worker's higher productivity at the job that offered the DB pension $\left(\mathrm{A}^{\mathrm{DB}}>\mathrm{A}^{\mathrm{DC}}\right) .^{7}$

The probabilities of staying with the firm are subjective, and are based on the employee's individual and family circumstances, as well as their assessment of the firm's prospects for profitability, and the likelihood that they will receive a more lucrative outside offer in the future.

The dependence of the value of a DB pension on the probability of remaining on the job suggests a series of possible explanations for the shift away from DB plans. A change in any condition that results in a lower $s_{\text {it }}$ will reduce the value of the back-loaded compensation scheme relative to an employment arrangement in which the worker is paid their marginal product in each period. In this light, the most obvious candidate explanation is the decline in job stability that has occurred in recent decades. ${ }^{8}$ Moreover, there is some evidence of a relationship between job mobility and pension portability: Coronado and Copeland (2004) found that industries with a higher share of workers who change jobs with no spell of unemployment were more likely to convert their traditional DB pension plans to cash balance plans that mimic the earlier benefit accrual and portability features of DC pensions.

In addition to the direct impact of changing job tenure, the shifting demographic composition of the labor force may also have changed the $s_{i t}$, thereby increasing the demand for flexible pensions. Among the most important of these demographic shifts is the entry of women into the labor force. Between 1979 and 1998, the share of workers who are female rose 16 percentage points. The rise in the share of women in the labor force has implied an increase in the share of workers who are caring for children or elderly parents. Caregivers have to balance demands for home production with their labor supply choices and may have less attachment to

7 In Lazear's model the efficient outcome is for equation 2 to be satisfied with equality. However, all that is required for an individual to take a job with a DB pension plan is that it equation 3 be satisfied with equality, which is not sufficient to guarantee the equality in equation 2 . Whether equation 2 holds with equality will depend on the search technology and is not important for our analysis.

8 Although it has been a matter of debate, the preponderance of the evidence suggests that job stability has declined. A thorough discussion of the topic can be found in Neumark (2000). 
either specific employers or the labor market more generally. In our data, women with children have lower job tenure than other workers even after controlling for sex, age and education.

The increase in the share of women in the labor force also implies an increasing share of workers, both men and women, who are in dual-earner households. Dual earners have to adjust their employment situation in response to changes in the employment situation of their spouse. Such joint decision-making could lead to greater mobility if a change in the employment situation of one spouse requires a change in the employment of the other; or to lesser mobility, since workers making such choices together may face greater constraints. In our data, members of dual earner couples have higher tenure, although we can not fully control for differences between members of dual-earner couples and other workers. The impact of a rise of dual earners on pension coverage is therefore an empirical issue.

Supply-side factors may also have played a role in the shift in pension coverage. Theoretical papers by Ippolito (2001), Friedberg and Owyang (2002) and Balan (2003) suggest that back-loaded DB pensions could become unstable in the face of changes in production technology that lead to an increase in the return to skills that are transferable across firms versus firm-specific skills. In terms of the equilibrium conditions we have specified, such a shift in technology would lower the value of $A^{D B}$ relative to $A^{D C}$, reducing the likelihood that equation 3 will be satisfied. Indeed there is empirical evidence to suggest that the return to human capital that is transferable across firms (general human capital) has risen faster than the return to firmspecific human capital in recent decades (Abowd, Lengermann, and McKinney, 2002).

Motivated by the fact that wage compensation is higher in jobs that offer DB pensions, some researchers have suggested that the positive association between pensions and tenure is not a consequence of the pensions themselves, but rather the result of the fact that jobs that provide pensions also provide other amenities, such as higher wages and health insurance, that make it less likely workers will leave the firm. This would suggest that changes in the provision of DB pensions will be positively correlated with wages and health benefits. A related story is that DB pensions are profit-sharing arrangements (Ippolito, 1994 and Gustman and Steimeier, 1992). In this case, a reduction in profit margins would reduce the ability of firms to offer implicit contracts such as traditional DB plans. Bertrand (2004) found evidence that, faced with increased international competition, employers in the U.S. are moving away from implicit contracts and towards spot markets for labor. 
Among the popular reasons cited for the shift from DB to DC pensions is the increase in federal regulation of private pension plans, beginning with the Employee Retirement Income Security Act of 1974 (ERISA). Regulation is thought to have imposed costs on firms that sponsor traditional DB pension plans, which, in turn, has reduced the attractiveness of these plans. Several early papers found that the trend away from DB plans could be explained only in part by industry characteristics and concluded that the trend owed in large part to high administrative and compliance costs that had been imposed on DB plan sponsors with the passage of ERISA. ${ }^{9}$

Regulation may also have constrained firms from adjusting plan parameters in response to changes in economic conditions. For example, life expectancy has increased considerably among the general population in the United States in recent decades. Holding the provisions of the pension contract constant, such a decrease in mortality would substantially raise the costs of offering a DB plan in which benefits are paid out as a life annuity. Employers could offset the effect of the rise in life expectancy by, among other things, raising the retirement age specified in their plan; however regulatory considerations under ERISA make this a difficult proposition (Muir and Turner, 2003). Thus, the increase in longevity combined with regulatory constraints on the firm's ability to alter plan provisions may lead employers to move toward DC pensions, in which benefits are paid out as a lump sum. Finally, conventional wisdom commonly cited in the popular press holds that increasing democratization of financial markets may have led workers to demand more control over their retirement portfolios.

The demographic shifts that affect employee demand for pensions and the changes in technological and competitive conditions that alter firm supply decisions differ across industries, allowing us to identify the influence of these variables on pension coverage. In contrast, federal regulation, changing mortality, and financial democratization affect all firms and workers and are difficult to identify with any data. In our approach, the effect of factors common to all firms will be measured residually.

\section{Empirical Strategy}

9. See Clark and McDermed (1990), Gustman and Steinmeier (1992) and Kruse (1995). The role of workforce demographics was not considered in these earlier studies. 
Underlying our empirical strategy for estimating the determinants of the evolution of pension coverage is a simple model of the supply and demand for pensions of a given type (either DB or DC). Start with implicit supply and demand functions in which price is a linear function of quantity and other factors, as in the following pair of equations

$$
\begin{aligned}
& p_{i j k t}^{D}=\alpha_{0 t}+\alpha_{1} q_{i j k t}+\mathbf{X}_{i j k t}^{D}{ }^{\prime} \boldsymbol{\alpha}+\mathbf{X}_{i j k t}^{B}{ }^{\prime} \boldsymbol{\delta}+\mu_{i}+\varphi_{t}+v_{i j k}+\varepsilon_{D i j k t} \\
& p_{j i k t}^{S}=\beta_{0 t}+\beta_{1} q_{j i k t}+\mathbf{X}_{j i k t}^{S}{ }^{\prime} \boldsymbol{\beta}+\mathbf{X}_{i j k t}^{B}{ }^{\prime} \boldsymbol{\theta}+\eta_{j}+\zeta_{t}+v_{i j k}+\varepsilon_{S j i k t}
\end{aligned}
$$

The top equation is the price $p^{D}$ that an individual $i$, working at firm $j$ in industry $k$ is willing to pay for a pension $q$ at time $t$. In this demand equation, $\mathbf{X}^{\mathbf{D}}$ is a vector of individual characteristics thought to determine the preference for pension coverage such as education and the presence of children. The supply equation, on the second line, is constructed analogously, with $\mathbf{X}^{\mathbf{s}}$ a vector of variables thought to determine the firm's decision to provide pension coverage, such as firm size and whether there is a union. Some variables are taken into account by both workers and firms, either because the same variable is actually used by both in making their decision or because we only observe the equilibrium outcome. In an example of the former, individuals' pension preferences may vary by age, while firms with different aged workforces may want to offer different types of plans. As an example of the latter, firms take into account their desired tenure when determining whether to offer a defined benefit or defined compensation pension plan, while individuals take into account their expected tenure when determining the type of pension they prefer. These may differ, but in our data we only observe the equilibrium outcome of tenure. Both these types of variables are denoted with an $\mathbf{X}^{\mathbf{B}}$.

In the structural equations, we allow for individual and firm preferences to vary over time ( $\varphi_{t}$ and $\zeta_{t}$ respectively). In addition there are individual and firm effects ( $\mu_{i}$ and $\eta_{j}$ respectively) and an individual/firm match specific effect $v_{i j k}$, which captures the fact that people sort into specific jobs rather than being randomly assigned. Unfortunately, we do not observe the underlying supply of and demand for pensions in our data, but rather the equilibrium outcome of firms' pension offerings and individual take-up rates. Thus we estimate the reduced form equation, in which supply is set equal to demand. The equation is the typical one:

$$
\begin{aligned}
& p_{i j k t}^{D}=p_{j i k t}^{S}:
\end{aligned}
$$

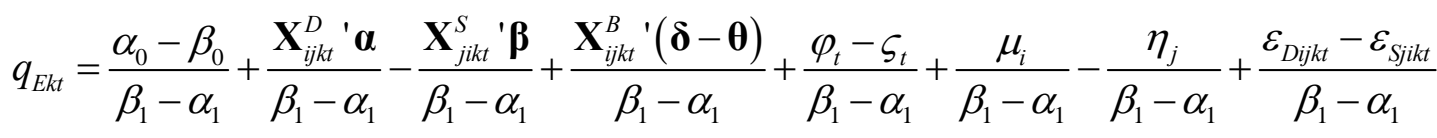


From this equation we cannot recover the structural parameters directly, but given exclusion restrictions we can know them up to a constant and compare their relative sizes. For variables that are taken into account by both firms and workers, such as age and tenure, we can't say anything about the structural parameters since the observed coefficient is a function of both the supply and demand effects. We only observe the behavior of the variable in equilibrium. ${ }^{10}$

Although we are interested in how pension coverage has changed over time, we don't observe individuals or firms over time. So we average the data at the industry level and then take differences. Relabeling the coefficients, the equation that we estimate is:

(6) $\Delta q_{E k t}=\frac{\Delta \varphi_{t}-\Delta \varsigma_{t}}{\beta_{1}-\alpha_{1}}+\frac{\Delta \overline{\mathbf{X}}_{i j k t}^{D}{ }^{\prime} \boldsymbol{\alpha}}{\beta_{1}-\alpha_{1}}-\frac{\Delta \overline{\mathbf{X}}_{j i k t}^{S}{ }^{\prime} \boldsymbol{\beta}}{\beta_{1}-\alpha_{1}}+\frac{\Delta \overline{\mathbf{X}}_{i j k t}^{B}(\boldsymbol{\delta}-\boldsymbol{\theta})}{\beta_{1}-\alpha_{1}}+\frac{\Delta \bar{\mu}_{i t}}{\beta_{1}-\alpha_{1}}-\frac{\Delta \bar{\eta}_{j}}{\beta_{1}-\alpha_{1}}+\frac{\Delta \bar{\varepsilon}_{D i j k t}-\Delta \bar{\varepsilon}_{\text {Sjikt }}}{\beta_{1}-\alpha_{1}}$

A couple of features of this equation are worth noting. First, the intercept captures (up to a scalar) the change in pension coverage due to aggregate factors affecting all workers and firms, such as changes in regulation. Second, because we average over individuals, the error term is heteroskedastic by construction. We correct for this by appropriately weighting the data. Third, the error term may include changes in the unobserved individuals and firms effects. Specifically, for a given person (firm) $\mu(\eta)$ is fixed, but we can't rule out that there might be changes in the average unobserved characteristics of individuals and firms in a particular industry. If these changes are correlated with changes in the explanatory variables, then the estimated coefficients may be biased. In order to reduce this problem, we include a variety of control variables, discussed in the data section, that we think absorb the larger part of these effects. We also estimate the equations using an instrumental variable technique and test the consistency of the SUR estimates.

\section{Data}

10 As we have modeled it here, the match-specific effect has the same factor loading in both the supply and demand equations (as if, for instance, it is measuring productivity which is equally valued by the firm and worker). As a result, it drops out of the reduced form equation. However, if the match effect had different factor loadings in the two equations and if the average industry match-specific effect changed over time then it would not drop out of the equation and it would be another potential source of omitted variable bias in equation 4 discussed below. A review of existing research suggests that sorting on health care coverage is minimal (Chernew et al., 2002). Although similar evidence does not exist for pension coverage, there is little reason to think that sorting on pension coverage would be greater. As is discussed below, we re-estimate our equations using instrumental variables, so this will control for the possibility that the match specific effect is biasing our results, along with other unobservables. 
We examine the change in pension offerings between 1979 and 1998. Information on pension coverage in the earlier period is obtained from the 1979 May supplement to the CPS, while data on pension coverage in the later period comes from the 1998 pension supplement to the 1996 panel of the SIPP. Our first task is to code the variables on pension coverage. In both surveys, the questions we are interested in refer to pension coverage at the current job. The CPS survey did not clearly delineate between DB and DC pension coverage. In the CPS, we define a person as being covered by a DB plan if they were covered by an employer-sponsored retirement plan but did not make contributions. Those who participated in an employer-sponsored retirement plan to which they contributed were considered to have DC coverage. The CPS also asks whether the individual participated in more than one plan. Since it would be very unusual for people to have two DB plans on a single job, and the limited array of DC plans relative to today's standards, people who reported having more than one pension are classified as having both.

This classification scheme has its drawbacks. While contributory DB schemes were unusual, such plans did exist in 1979 and were concentrated in a handful of industries (mainly automobile manufacturers and petroleum companies). For example, a survey of the 50 largest pension sponsors in 1979 indicated that seven had DB schemes with mandatory contributions (The Wyatt Company, 1980). However, all of these plans also had supplementary thrift plans, so if employees participated in both plans we would correctly classify them as having dual coverage. Furthermore, on aggregate we match coverage statistics based on administrative data sources quite well (see below), so the problem seems limited. To the degree we have some misclassification, it will add noise to our coverage measures leading to larger standard errors. If the measurement error is correlated with our explanatory variables this will be resolved in our IV estimation.

Data from the 1998 SIPP had better indicators of pension type. For up to two pension plans, respondents were asked whether their benefits in that plan based on earnings and years of service or balances in individual accounts. Those whose benefits were based on earnings and years of service were classified as having DB plans and those whose plans featured individual accounts were classified as having DC coverage. Again, given that individuals rarely have two DB plans we assume that individuals with more than one plan, who report that one plan is DB, have one of each type. However, given the greater variety in DC coverage by 1998, we allow for 
the possibility that individuals have two DC plans. ${ }^{11}$

As a validation exercise, we compared the coverage rates that resulted from our classification scheme with coverage rates from Form 5500 filings that private sector pension sponsors must file with the Department of Labor annually. The results are shown in Table 2. Sponsoring firms report the number of participants by plan; thus, people who participate in more than one plan are double counted. To facilitate the comparison we also double counted people with dual coverage in the CPS and SIPP data. The proportion of workers with defined benefit and defined contribution plans in the CPS and SIPP are remarkably similar to the proportions gleaned from the 5500 data suggesting that our classification scheme is sound.

Our premise is that changes in the composition of the labor force and changes in the nature of production have shifted pension coverage toward more portable plans. Although our analysis is reduced form, we roughly divide up our variables into demand-side factors, relating to the changing needs of individuals in the labor force, and supply-side factors relating to changes in firm characteristics. As measures of potentially low job attachment we use the proportion of individuals in a given industry who are women with children or part of a dual-earner couple. In addition we include a number of demographic variables to control for individual effects that may be correlated with pension coverage but that may or may not directly affect demand, such as age, sex, education, and region of residence. These variables are all constructed from the CPS and SIPP and then aggregated to the industry level as in equation 6. In the CPS, the variables identifying whether an individual has children and whether he or she is part of a dual-earner couple were calculated by matching individuals in the May CPS to their survey responses in the March CPS. ${ }^{12,13}$ The tenure variable, which as we noted is actually an equilibrium outcome, is

11 Since we have no information on other plans, this coding allows individuals to have no more than 2. However, as can be seen in Table 1, we are still able to replicate the administrative data on pension coverage well.

12 The CPS is designed so that individuals are surveyed for four months in a row and can be matched across months. The May pension supplement was only administered to individuals who took part in the March survey (half of the sample administered the basic May CPS survey), and the Census itself merged March earnings and income variables into the May file. However, we require additional data to calculate the family-related variables and so rematched the data. Individuals are matched by household identifiers, their line number (which is not an exact identifier in 1979) and then age and sex. Occasionally it is not possible to make a match. Individuals in the March survey would not have been interviewed in May if they changed residences between the two surveys or they may simply have failed to respond to the survey. There may also be error in the matching process. We use the March data merged in by the Census to validate our own matching process. In 1979, 24,414 people responded to the May supplement and the Census merged in March data for 22,879. We were able to match 21,822 people from the May supplement to the March supplement, and of these all but 7 had March wage and salary income equal to the corresponding variable that the Census had merged in. Individuals for whom this data did not match were 
also calculated from the May CPS and SIPP tenure supplements.

We also include a variety of variables to capture a firm’s propensity to supply different types of pensions, motivated by the theories discussed in the previous section. Technical change at the industry level is measured as the growth in multifactor productivity between 1979 and 1998 using data from Gullickson and Harper (2002). Another way we capture the movement toward a more high-tech workplace is the change in the proportion of workers in the industry in professional and technical occupations, constructed using the CPS and SIPP data. To capture the change in industry rents we use the change in the average return to capital in the industry, again calculated from data in Gullickson and Harper (2002). Perhaps because of economies of scale, large firms are more likely to offer pension coverage generally and DB coverage in particular, so we include the proportion of firms with at least 100 employees within the industry. The proportion of workers covered by a union contract is also likely to affect pension provision. These two variables are gleaned from the CPS and SIPP. We also include a number of variables to try to control for changes in firm characteristics that may be correlated with but not the cause of changes in pension coverage, including the change in the average industry wage, the change in the proportion of firms offering health plans, and the change in industry employment (all calculated from the March CPS).

Finally, over this period many firms were converting their DB plans to cash balance plans, which, although still considered DB plans, mimic the earlier benefit accrual and portability features of DC pensions. In industries in which trends in demographic and firm characteristics lead some firms to opt for DC pensions, firms with existing DB plans may instead take the cash balance route, making it more difficult for us to find a relationship between our explanatory variables and the change in DB coverage. Similarly, the conversion to cash balance conversions may substitute for the introduction of DC plans, again attenuating the relationships we are trying to identify. Since cash balance conversions have the potential to confound our results, we

eliminated from the sample.

13 We calculated the number of children ourselves, because the Census-provided child variables are not consistent across the CPS and SIPP. In the CPS, the variable refers only to the own children of the primary family (the family including the householder). So for instance, a grandchild would not be counted as part of any family even if the child's mother also lived in the house, forming what the CPS calls a subfamily. In our variable we allocate children to the adults of the subfamily (the mother in this example), if they are a member of one, and to the primary family if not. For consistency, we used the same method was used to calculate number of children in the SIPP, although that survey includes variables that could have been used to obtain a similar measure. 
control for them using variables on the number of cash balance plans and the number of participants in those plans in 1999 by industry, which was calculated by staff at the Department of Labor using data from 5500 filings. ${ }^{14}$

\section{Results}

To ascertain how supply and demand factors explain the decline in defined benefit pensions and the rise in defined contribution plans, we estimate equation 6 using the change in the proportion of individuals in the given industry with a DB plan and the change in the proportion of individuals in the given industry with a DC plan as the dependent variables. The equations are estimated jointly using Seemingly Unrelated Regression, using data on 40 2-digit industries.

As was described in the background section, there was considerable variation in the changes in pension coverage across industries (Table 1). As Table 3 makes clear, there was also substantial dispersion in the change in industry characteristics (based on the 2-digit industries). For instance, the proportion of workers in dual-earner couples rose 24 percentage points on average between 1979 and 1998, but the standard deviation was 7.8 percentage points. So while some industries, such as personal services and leather and apparel manufacturers, experienced hardly any increase, others, including many durable manufacturing industries experienced increases of around 35 percent (not shown). Moreover, while the proportion of workers with less than 5 years of experience barely increased on average across industries, the standard deviation of the change was 7.6 percent, with auto repair services, education, and real estate all experienced increases above 10 percentage points, while chemical manufacturers and the communications industry experienced increases of 15 percentage points or more (not shown). These tables suggest that we have the variation necessary to identify the factors affecting the shift in pension coverage over the past 20 years.

Table 4 presents the results of estimating equation 6 . Our baseline specification is shown in the first set of columns. The fit of the regression, measured by the R-square is good, which is not surprising since we are eliminating a good deal of noise by averaging individual data within

14 Since there were no cash balance plans in 1979, these variables also represent the change in cash balance plans between 1979 and 1998. 
industries. We do a better job of explaining changes in DB coverage than in DC coverage.

The results provide support for both our demand and supply-side stories. To start, it appears that the decline in DB coverage has been associated with shorter employment relationships: industries that experienced a rise in the proportion of workers with less than five years of tenure experienced significantly larger declines in DB pension coverage. Conversely, a rise in low-tenure workers is correlated with an increase in DC coverage. Both these results are statistically significant at the one percent level. As noted above, the coefficients on this variable combine both the impact of worker demand for pension coverage and firm supply. One difficulty in interpreting these results is the potential endogeneity of tenure; that is, a reduction in DB coverage may result in reduced employer attachment. We will explore this possibility below.

We also find support for our hypothesis that some workers may prefer the portability of a DC pension plan. As we noted above, one group likely to desire such portability is dual- earner couples, who may make joint decisions about their employment. As can be seen Table 4, after controlling for characteristics such as age, marital status, and actual tenure, it appears that an increase in the share of dual earners in an industry is strongly associated with reduced DB coverage and increased DC coverage. ${ }^{15}$

Another group that we argued might demand portability is women with children. Indeed our results show that industries seeing an increase in the share of female workers with children saw a larger decline in their DB coverage. However, industries with a greater share of females with children did not see a rise in their DC coverage, which if our empirical model is correct suggests that these workers don't have a demand for DC pension coverage---perhaps preferring higher wages instead.

On the supply side, we were interested in the hypothesis that more rapid changes in production technology increase mobility, perhaps, as some models have suggested, by reducing the demand for firm-specific human capital. Our results suggest that industries that experienced more rapid MFP growth did reduce their provision of defined benefits plans and increased their

15 The demand for flexibility may be particularly strong for the secondary earner in a dual-earner couple. So as an alternative we included a variable that measures the share of family earnings accounted for by workers in a given industry. It was indeed the case that industries whose workers accounted for a reduced share of household earnings were significantly more likely to reduce DB coverage and increase DC coverage. However, since a worker's share of family earnings depends on their wages and hours worked, factors that may be correlated with pension coverage, we focus on whether the worker is in a dual-earner couple instead. 
provision of defined contribution plans. Similarly, industries that increased the proportion of professional and technical workers saw statistically significant declines in DB coverage and increases in DC coverage.

Our results call into question the hypothesis that the relationship between pension provision and tenure simply reflects higher job quality for those with pensions, since we find a correlation between declines in tenure and declines in DB coverage, conditional on variables that should capture job quality such as the percent change in the average weekly wage in the industry, changes in health care coverage, and changes in average firm size (which has been shown to be positively associated with wages and benefits provision).

Evidence on the relationship between pensions and rent sharing is mixed. The change in the return to capital is not correlated with the change in either DB or DC coverage. However, unions have traditionally been thought to bargain over rents, and we find that a reduction in union coverage is correlated with reductions in both DB and DC coverage (although in the latter case only at the 10-percent level). This suggests that unions have been effective at negotiating pension benefits of both types for their employees, whether related to rent sharing or not.

Of the control variables, those concerning the conversion of DB pension plans to cash balance plans are of particular interest since, like DC plans, cash balance plans do not penalize job change. In fact, we see that industries that experienced a greater increase in the number of cash balance plans and in the proportion of workers covered by such plans also experienced larger increases in DC plans. The variables are statistically significant at the 1 percent and nearly the 5 percent level respectively. These variables are not statistically significant in the DB equations.

We included a variety of other control variables to try to capture changes in the characteristics of the firms and workers that might be correlated with changes in pension coverage. One interesting finding is that industries that employ better educated workers were less likely to drop DB coverage as can be seen from the variables capturing the change in proportion of workers with a high school degree, some college, and a college degree (workers with less than a high school degree are the left-out group). In contrast, industries that saw an increase in the educational attainment of their workers were less likely to add DC coverage. This would seem to contradict the story that an increase in the relative importance of general human capital has contributed to the cutback in DB pension provision. However, it appears that 
conditional on our inclusion of the MFP growth and professional and technical workers variables, the education variables may be capturing other individual or job characteristics, besides general human capital. If we leave out these two more direct effects of technical change and skill demand, the coefficient on the college education dummy variable because much smaller and is statistically insignificant in the DB equation. In the DC equation the coefficients on the some college and college education dummy variable flip sign. So while our findings do not provide direct evidence that more rapid technical change and the demand for skill reduces DB coverage through its affect on the relative demand for general human capital, they are suggestive of this connection. We also include a variety of variables aimed at controlling for firm and industry characteristics. The percent change in the average weekly wage (which actually should capture changes in worker quality as well as changes in job quality) is not statistically significant in either equation nor is a variable indicating whether an industry increased or decreased its employment share. We include the change in the share of workers in the industry covered by own-employer-provided health insurance on the theory that accounting for changes in other parts of the benefits package should help to control for unobservable firms changes that might also affect pension coverage. Interestingly an increase in the share of workers covered by health plans is negatively correlated with the change in DB pension coverage and positively related to the rise in DC pension coverage, although this latter result is not statistically significant. Taken together these results do not indicate a consistent relationship between variables that capture firm or industry well-being and the provision of pension coverage.

To confirm our results, we perform a number of robustness checks. The most obvious potential problem is endogeneity. As was mentioned previously, the shift from DB to DC pension coverage could have reduced the incentive for long-term contracts, lowering tenure rather than the other way around. In addition, it is possible that changes in the unobserved characteristics of individuals or firms within industries are correlated with our explanatory variables. To reduce this possibility, we included the broad array of controls for individual and firm characteristics discussed above.

Despite the inclusion of control variables, endogeneity may still be a problem, so we reestimate our two equations jointly using three-stage least squares (3SLS). We instrument for the characteristics that we fear are the most likely to be endogenous, either due to reverse causality or due to worker sorting. These include the change in the proportion of workers with less than 5 
years of tenure, the change in the proportion of women in the industry, the change in the proportion nonwhite, the change in average worker age (and higher order terms), the change in education (three dummy variables), the change in the proportion of workers that are married, the change in the share of workers in dual-earner couples, the change in the proportion of workers that are women with children, the percent change in the average industry wage, the change in the proportion of profession/technical workers, and the change in industry employment share. As instruments we use lagged changes in these variables (the change from 1968 to 1978), since lags likely capture long-run demographic changes that are correlated yet predetermined. We also use lagged changes in the share of workers in 5 birth cohorts (covering birth years 1904 through 1961), since labor force, marital, and fertility patterns have varied significantly across cohorts.

The results of the IV estimation suggest that our SUR estimates are consistent. The first stage regressions, not shown, fit well, with R-squared statistics mostly over $0.8 .{ }^{16}$ A Hausman test yields a statistics of 11.2, which fails to reject the consistency of the SUR estimates at any level. Moreover, as can be seen by comparing the results in columns 1 and 2 with columns 3 and 4 respectively, the two estimation methods yield very similar results. The main difference is that the standard errors are much larger in the DC equation so fewer of the coefficients are statistically significant. Based on these results, we continue to focus our attention on our baseline specification.

Another aspect of our estimation that we explore is whether our result on dual earner couples is being driven by their demand for more portable pensions or whether it is a proxy for some other factor. In our data, individuals in dual-earner couples have higher tenure, even after conditioning on age, sex, education and marital status. This would seem to suggest that we might observe the opposite result---these couples would have a greater demand for DB pension plans. However, it could be that tenure itself is the result of other characteristics of individuals in dual earner couples that we don't observe, and that all else equal these workers might have a greater demand for portable pensions. To disentangle this story we rerun the SUR specification without the tenure variable, the results of which are shown in the $5^{\text {th }}$ and $6^{\text {th }}$ columns of Table 4 . In this case, the coefficient on the change in the share of workers who are in dual earner couples becomes smaller in absolute value in both the DB and DC equations and loses its statistical significance in the latter. This suggests that the positive correlation between tenure and being

16 The exceptions are the education variables, for which the fit is less good. 
part of a dual-earner couple may be attributable to the unobserved characteristics of these workers, who, ceteris paribus do prefer greater portability.

While an examination of the coefficients suggests that both supply and demand factors have played an important role in explaining the shift from DB to DC pension plans, it does not provide much information about the contribution of these factors to the variation in pension coverage shifts across industries. To provide a better understanding of the relative magnitudes of the various factors, as well as their overall effect, Figures 2 and 3 graph the impact, on DB and DC pension coverage respectively, of a one standard deviation change in the most pertinent explanatory variables. Turning first to DB coverage, we see that a one standard deviation increase in the share of workers with less than five years of experience causes a 7.1 percentage point decline in DB coverage. On the demand side, a one standard deviation increase in the share of dual-earner couples reduces DB coverage by 5.3 percentage points, while a one standard deviation increase in the share of women with children decreases DB coverage by about 4.5 percentage points. Overall, the net impact of these demographic characteristics is a bit larger than the impact of changes in firm characteristics. Among firm characteristics, the variables capturing technical change are particularly important, with a one standard deviation faster multifactor productivity growth and a one standard deviation increase in the share of professional and technical workers reducing DB pension coverage by 3.7 percentage points and 5.7 percentage points respectively. A one standard deviation decrease in the proportion of workers covered by a union contract reduces DB coverage by 3.6 percent.

There is significant overlap between the variables associated with a decline in DB coverage and those associated with a rise in DC coverage. As can be seen in Figure 3, a onestandard-deviation rise in the share of low-tenure workers increases DC coverage by about 3.7 percentage points. With respect to the demand-side variables, a one standard deviation increase in the proportion of workers in dual-earner couples increases DC coverage by 2.5 percentage points. However, unlike the DB equation a change in the proportion of women with children is neither statistically or economically important in explaining the rise in DC coverage. On the firm side, the largest increase in DC coverage results from the rise in the share of professional and technical workers, with a one standard deviation increase in the share of such workers raising DC coverage by nearly 4.0 percentage points. In addition, a one standard deviation increase in the growth rate of multifactor productivity increases DC coverage by about 1.2 
percentage points. However, industries that experienced a one standard deviation greater decline in unionization saw their DC coverage fall 2.5 percentage points ceteris paribus.

The preceding analysis suggests that changes in demographic characteristics and production processes can explain much of the variation in pension coverage trends across industries. However, it is also of interest to compare the importance of the supply and demandside factors we focus on relative to the aggregate factors measured residually in the intercept. Since we have a number of dummy variables in our equations, the intercept represents the change in DB or DC coverage for unmarried white male high school drop-outs living in New England with more than five years of tenure who are not covered by union contracts and are not Professional or technical workers. The impact of our explanatory variables is calculated by summing the effect of changes in our primary explanatory variables (those shown in Figures 2 and 3) when those variables are at their mean. Altogether these variables predict a 12 percentage point decline in DB coverage, about half as much as our estimate of the aggregate factors. However, our explanatory variables together explain almost none of the average decline in DC coverage. The relatively small impact of our explanatory variables on the aggregate shift in pension coverage can be explained in part by the fact that while there were significant differences in the changes in the explanatory variables across industries (as can be seen by the standard deviations of the changes in our explanatory variables in Table 3), on average some of these variables did not change very much, as can be seen by looking at the average change in the same table. Moreover, the amount of the rise in DC coverage that we explain with our variables is reduced by the fact that the decline in union coverage, which was large on average, served to decrease DC pension coverage. If we omit unionization from our analysis then the remainder of our explanatory variables predict a 3.5 percentage point rise in DC coverage, about 12 percent as much as the aggregate factors.

\section{Conclusion}

Employer-provided pensions account for about 20 percent of household income for today's retirees, so changes in the structure of pensions may have important implications for retiree well-being. In this paper we have explored the shift in pension coverage from DB plans to DC plans. We find that, while there is clearly a general move away from DB plans owing to factors such as regulatory burden or increased life-expectancy that affect all firms, it is also the 
case that industries with a shift in demographic and firm characteristics that tend to favor more flexible employment contracts experienced a significantly larger increase in DC pension coverage and decline in DB pension coverage.

Because we do not observe the individual supply and demand for pensions our results are equilibrium outcomes. However, given restrictions on which variables affect supply and demand, they also provide information about the relative importance of the factors in shaping underlying supply and demand. Based on robustness tests, our empirical specification appears to control adequately for heterogeneity that could bias our results. Thus we believe our findings provide insight into the factors underlying the dramatic shift in pension coverage.

These results suggest that in the current environment certain workers and firms prefer pension plans that do not penalize job change. Going forward, it is difficult to predict how changes in production and competitive environments will shape compensation contracts. Although we are unlikely to observe the rates of change in the workforce demographics of the magnitude seen over the previous thirty years, changes in production processes could continue to favor the shift toward more flexible compensation. These results suggest that some public policy effort should focus on the retirement security issues posed by DC pensions such as participation and investment choices during the working years, and managing lump-sum distribution of benefits upon retirement. In addition, the move toward more even benefit accrual and portability within the DB framework that occur with a cash balance conversion may be a positive development for the retirement security of many covered workers. 


\section{References}

Abowd, John M., Paul A. Lengermann, and Kevin L. McKinney. 2002. “The Measurement of Human Capital in the U.S. Economy.” U.S. Census Bureau Longitudinal Employer-Household Dynamics Technical Paper No. TP-2002-10.

Balan, David J. 2003. “Have Lazear-Style Implicit Contracts Disappeared?” Federal Trade Commission Working Paper 256.

Bertrand, Marianne. "From the Invisible Handshake to the Invisible Hand? How Import Competition Changes the Employment Relationship." Journal of Labor Economics, 2004, 22(4), pp. 723.

Chernew, Michael E., and Richard A Hirth. 2002. "Modeling the Causes and Consequences of Lack of Health Insurance Coverage: Gaps in the Literature. ERIU Working Paper 1, University of Michigan.

Clark, Robert and Ann A. McDermed, The Choice of Pension Plans in a Changing Regulatory Environment, (Washington D.C.: The AEI Press, 1990).

Coronado, Julia Lynn and Philip C. Copeland. 2004. "Cash Balance Pension Plan Conversions and the New Economy.” Journal of Pension Economics and Finance. 3(3): 1-18.

Even, William, and David MacPherson. 1996. "Employer Size and Labor Turnover: The Role of Pensions”. “Industrial Labor Relations Review”. 49(4): 707-28 2001. "Benefits and Productivity" Benefits for the Workplace of Tomorrow”. Philadelphia: Pension Research Council

Fallick, Bruce C., and Charles A. Fleischman. 2001. “The Importance of Employer-toEmployer Flows in the U.S. Labor Market”. Finance and Economics Discussion Series Working Paper 2001-18.

Friedberg, Leora and Michael T. Owyang. 2002. "Explaining the Evolution of Pension Structure and Job Tenure.” Federal Reserve Bank of St. Louis Working Paper 2002022A.

Gullickson, William and Michael J. Harper. 2002. Bias in Aggregate Productivity Trends Revisited; By Monthly Labor Review, 125(3): pp. 32-40

Gustman, Alan L., Olivia S. Mitchell, and Thomas Steinmeir. 1994. "The Role of Pensions in the Labor Market: A Survey of the Literature.” Industrial and Labor Relations Review 47(3): 417-438 
Gustman, Alan L. and Thomas L. Steinmeier. 1992. "The Stampede Toward Defined Contribution Pension Pland: Fact or Fiction?” Industrial Relations 31(2): 361-69.

Hutchens, Robert. 1989. “Seniority, Wages, and Productivity: A Turbulent Decade”. Journal of Economic Perspectives, 3(4): 49-64

Ippolito, Richard A. 2001. “Issues Surrounding Cash Balance Plans.” Benefits Quarterly Third Quarter 2001:30-45 . 1995. "Toward Explaining the Growth of Defined Contribution Plans.” Industrial Relations 34(1): 1-20. 795-812 , 1994. “Pensions and Indenture Premia” Journal of Human Resources 29(3):

Kruse, Douglas L. 1995. "Pension Substitution in the 1980s: Why the Shift Toward Defined Contribution?” Industrial Relations 34(2): 218-241.

Laibson, David I., Andrea Repetto, and Jeremy Tobacman. 1998. "Self-Control and Saving for Retirement”. Brookings papers on Economic Activity, 1998(1): 91-196

Lazear, Edward P. 1979. “Why Is There Mandatory Retirement?” Journal of Political Economy, 87(6): 1261-84

Mitchell, Olivia S., 1990. “Aging, Job Satisfaction, and Job Performance” In I. Bluestone, R. Montgomery, and J. Owen, eds., An Aging Workforce. Detroit: Wayne State University Press, 242-72

Muir, Dana and John Turner. 2004. "What Underlies the Shift Away from Defined Benefit Pension Plans?” mimeo. University of Michigan.

Neumark, David, 2000, "Changes in Job Stability and Job Security: A Collective Effort to Untangle, Reconcile, and Interpret the Evidence," in David Neumark, Ed., On the Job: Is Long-Term Employment a Thing of the Past? (New York: Russell Sage Foundation), pp. 70-110.

Papke, Leslie E. 2000. “Are 401(k) Plans Replacing Other Employer-Provided Pensions?” Journal of Human Resources 34(2): 346-368.

The Wyatt Company. 1980. "Survey of Retirement, Thrift, and Profit-Sharing Plans Covering Salaried Employees of the 50 Largest U.S. Industrial Companies as of January 1, 1980." 
Table 1 - Changes in Pension Coverage by Industry Ranked by DB Decline

\begin{tabular}{|c|c|c|c|c|}
\hline Industry & $\begin{array}{r}\text { DB Coverage } \\
1979\end{array}$ & $\begin{array}{r}\text { DC Coverage } \\
1979\end{array}$ & $\begin{array}{r}\text { Change in } \\
\text { DB Coverage } \\
1998-79 \\
\end{array}$ & $\begin{array}{r}\text { Change in } \\
\text { DC Coverage } \\
1998-79 \\
\end{array}$ \\
\hline & \multicolumn{4}{|c|}{ Percentage point change } \\
\hline 1. Textiles & 49.3 & 17.8 & -39.1 & 17.8 \\
\hline 2. Fabricated Metals & 54.5 & 23.6 & -36.7 & 23.6 \\
\hline 3. Communications & 63.0 & 26.4 & -35.9 & 26.4 \\
\hline 4. Petroleum & 62.4 & 38.1 & -34.2 & 38.1 \\
\hline 5. Stone, clay \& glass & 57.3 & 25.1 & -33.9 & 25.2 \\
\hline 6. Mining & 48.8 & 18.1 & -33.4 & 18.1 \\
\hline 7. Primary metals & 65.4 & 21.3 & -33.0 & 21.3 \\
\hline 8. Machinery, except electrical & 52.1 & 27.7 & -31.8 & 27.7 \\
\hline 9. Food & 49.9 & 15.2 & -29.2 & 15.2 \\
\hline 10. Rubber \& plastics & 49.7 & 30.0 & -29.0 & 30.0 \\
\hline 11. Professional equip. \& instruments & 50.2 & 31.2 & -28.8 & 31.2 \\
\hline 12. Misc. manufacturing & 42.5 & 18.3 & -27.1 & 18.3 \\
\hline 13. Chemicals & 57.1 & 22.6 & -26.7 & 22.6 \\
\hline 14. Other public utilities & 57.8 & 29.7 & -26.4 & 29.7 \\
\hline 15. Electrical Equipment & 44.4 & 22.8 & -25.9 & 22.8 \\
\hline 16. Transportation equipment & 60.3 & 22.1 & -25.4 & 22.1 \\
\hline 17. Wholesale trade & 38.5 & 20.6 & -25.4 & 20.6 \\
\hline 18. Paper & 57.5 & 20.9 & -25.2 & 20.9 \\
\hline 19. Banking \& other finance & 44.6 & 22.6 & -23.5 & 22.6 \\
\hline 27. Motion pictures & 29.2 & -8.3 & -22.5 & -8.3 \\
\hline 21. Leather & 38.4 & 16.9 & -22.5 & 1.7 \\
\hline 22. Furniture \& fixtures & 40.0 & 24.1 & -22.2 & 24.1 \\
\hline 23. Transportation & 36.5 & 7.8 & -20.7 & 7.8 \\
\hline 24. Professional services & 28.9 & 16.1 & -17.9 & 16.1 \\
\hline 25. Printing & 32.5 & 19.5 & -17.0 & 19.5 \\
\hline 26. Lumber \& wood products & 31.4 & 21.7 & -16.7 & 21.7 \\
\hline 27. Business services & 22.2 & 18.4 & -15.8 & 18.4 \\
\hline 28. Insurance & 42.8 & 18.6 & -15.4 & 18.6 \\
\hline 29. Medical & 31.3 & 19.3 & -14.8 & 19.3 \\
\hline 30. Construction & 25.2 & 6.7 & -14.0 & 6.7 \\
\hline 31. Apparel & 29.3 & 17.1 & -11.6 & 17.1 \\
\hline 32. Retail trade & 18.3 & 9.4 & -10.3 & 9.4 \\
\hline 33. Hotels \& other lodging & 17.0 & 13.5 & -10.3 & 13.5 \\
\hline 34. Auto repair services & 11.8 & 12.3 & -7.9 & 12.3 \\
\hline 35. Amusement \& recreation services & 11.3 & 14.9 & -7.4 & 14.9 \\
\hline 36. Agriculture & 10.0 & 5.5 & -5.7 & 5.5 \\
\hline 37. Personal services & 7.2 & 6.9 & -5.5 & 6.9 \\
\hline 38. Real estate & 11.5 & 18.3 & -3.8 & 18.3 \\
\hline 39. Forestries \& fisheries & 6.9 & 9.7 & -3.0 & 9.7 \\
\hline 40. Education & 15.2 & 13.6 & -1.0 & 13.6 \\
\hline TOTAL & 35.1 & 19.4 & -21.1 & 14.1 \\
\hline
\end{tabular}


Table 2 -Type of Pension Coverage from the CPS and SIPP and Form 5500 Filings with the Department of Labor

(percent)

\begin{tabular}{lccc}
\hline & CPS and SIPP & Form 5500 \\
\hline & & 1979 & \\
DB & 64.9 & & 62.7 \\
DC & 35.1 & & 37.3 \\
& & 1998 & \\
DB & 29.7 & & 31.4 \\
DC & 70.3 & & 68.6 \\
\hline
\end{tabular}

Table 3 -Selected industry characteristics at the 2-digit Industry Level (Percentage point change 1998-1979)

\begin{tabular}{lrr}
\hline Variable & Mean & Std. Dev. \\
\hline Married workers & -7.4 & 6.4 \\
Workers in dual-earner couples & 1.6 & 7.8 \\
Women with children & 0.7 & 4.7 \\
Professional and technical workers & 3.9 & 5.6 \\
Firms with 100+ workers. & 0.1 & 9.8 \\
Average return to capital & -7.3 & 39.1 \\
Workers with < five years of tenure & 0.5 & 7.6 \\
Memo: Growth in Multifactor & 7.7 & 24.0 \\
productivity & & \\
\hline
\end{tabular}




\section{Table 4 - Estimation of the Change in the Share of Workers Covered by a DB or DC Pension Plan between 1979 and 1998}

\begin{tabular}{|c|c|c|c|c|c|c|}
\hline \multirow[b]{3}{*}{ Variable } & \multicolumn{2}{|c|}{ (1) } & \multicolumn{2}{|c|}{ (2) } & \multicolumn{2}{|c|}{ (3) } \\
\hline & \multicolumn{2}{|c|}{ SUR } & \multicolumn{2}{|c|}{$3 S L S$} & \multicolumn{2}{|c|}{ SUR } \\
\hline & $D B$ & $D C$ & $D B$ & $D C$ & $D B$ & $D C$ \\
\hline female & $\begin{array}{c}0.518 \\
(0.142)^{* *}\end{array}$ & $\begin{array}{c}0.069 \\
(0.201)\end{array}$ & $\begin{array}{c}0.675 \\
(0.290)^{*}\end{array}$ & $\begin{array}{c}0.325 \\
(0.347)\end{array}$ & $\begin{array}{c}0.926 \\
(0.232)^{* *}\end{array}$ & $\begin{array}{l}-0.146 \\
(0.214)\end{array}$ \\
\hline married & $\begin{array}{c}0.348 \\
(0.164)^{*}\end{array}$ & $\begin{array}{c}0.225 \\
(0.232)\end{array}$ & $\begin{array}{c}0.441 \\
(0.337)\end{array}$ & $\begin{array}{c}0.663 \\
(0.403)\end{array}$ & $\begin{array}{c}0.801 \\
(0.269)^{* *}\end{array}$ & $\begin{array}{c}-0.014 \\
(0.249)\end{array}$ \\
\hline female w/child & $\begin{array}{c}-1.182 \\
(0.178)^{* *}\end{array}$ & $\begin{array}{c}-0.033 \\
(0.252)\end{array}$ & $\begin{array}{c}-1.527 \\
(0.321)^{* *}\end{array}$ & $\begin{array}{l}-0.246 \\
(0.384)\end{array}$ & $\begin{array}{c}-1.379 \\
(0.305)^{* *}\end{array}$ & $\begin{array}{c}0.072 \\
(0.282)\end{array}$ \\
\hline dual-earner couple & $\begin{array}{c}-0.986 \\
(0.118)^{* *}\end{array}$ & $\begin{array}{c}0.466 \\
(0.167)^{* *}\end{array}$ & $\begin{array}{c}-1.045 \\
(0.217)^{* *}\end{array}$ & $\begin{array}{c}0.025 \\
(0.259)\end{array}$ & $\begin{array}{c}-0.627 \\
(0.192)^{* *}\end{array}$ & $\begin{array}{c}0.277 \\
(0.177)\end{array}$ \\
\hline nonwhite & $\begin{array}{c}-1.319 \\
(0.152)^{* *}\end{array}$ & $\begin{array}{c}0.368 \\
(-0.215)\end{array}$ & $\begin{array}{c}-1.357 \\
(0.275)^{* *}\end{array}$ & $\begin{array}{c}0.111 \\
(0.329)\end{array}$ & $\begin{array}{c}-0.417 \\
(0.195)^{*}\end{array}$ & $\begin{array}{c}-0.107 \\
(0.181)\end{array}$ \\
\hline age & $\begin{array}{c}-0.196 \\
(0.123)\end{array}$ & $\begin{array}{c}0.535 \\
(0.174)^{* *}\end{array}$ & $\begin{array}{c}-0.39 \\
(0.226)\end{array}$ & $\begin{array}{c}0.786 \\
(0.270)^{* *}\end{array}$ & $\begin{array}{c}0.148 \\
(0.202)\end{array}$ & $\begin{array}{c}0.354 \\
(0.187)\end{array}$ \\
\hline age2 & $\begin{array}{c}0.006 \\
(0.003)\end{array}$ & $\begin{array}{c}-0.016 \\
(0.005)^{* *}\end{array}$ & $\begin{array}{c}0.012 \\
(0.006)\end{array}$ & $\begin{array}{c}-0.022 \\
(0.007)^{* *}\end{array}$ & $\begin{array}{l}-0.003 \\
(0.005)\end{array}$ & $\begin{array}{c}-0.011 \\
(0.005)^{*}\end{array}$ \\
\hline age3 & $\begin{array}{l}0.000 \\
0.000\end{array}$ & $\begin{array}{c}0.000 \\
(0.000)^{* *}\end{array}$ & $\begin{array}{c}0.000 \\
(0.000)^{*}\end{array}$ & $\begin{array}{c}0.000 \\
(0.000)^{* *}\end{array}$ & $\begin{array}{l}0.000 \\
0.000\end{array}$ & $\begin{array}{c}0.000 \\
(0.000)^{*}\end{array}$ \\
\hline high-school & $\begin{array}{c}0.753 \\
(0.136)^{* *}\end{array}$ & $\begin{array}{c}-0.308 \\
(0.193)\end{array}$ & $\begin{array}{c}0.956 \\
(0.253)^{* *}\end{array}$ & $\begin{array}{c}0.162 \\
(0.303)\end{array}$ & $\begin{array}{c}0.439 \\
(0.227)\end{array}$ & $\begin{array}{c}-0.143 \\
(0.21)\end{array}$ \\
\hline some college & $\begin{array}{c}0.809 \\
(0.119)^{* *}\end{array}$ & $\begin{array}{c}-0.033 \\
(0.168)\end{array}$ & $\begin{array}{c}1.105 \\
(0.230)^{* *}\end{array}$ & $\begin{array}{c}0.299 \\
(0.275)\end{array}$ & $\begin{array}{c}0.275 \\
(0.177)\end{array}$ & $\begin{array}{c}0.248 \\
(0.164)\end{array}$ \\
\hline college & $\begin{array}{c}2.181 \\
(0.341)^{* *}\end{array}$ & $\begin{array}{c}-0.984 \\
(0.482)^{*}\end{array}$ & $\begin{array}{c}2.519 \\
(0.647)^{* *}\end{array}$ & $\begin{array}{l}-0.402 \\
(0.774)\end{array}$ & $\begin{array}{c}0.048 \\
(0.418)\end{array}$ & $\begin{array}{c}0.141 \\
(0.387)\end{array}$ \\
\hline$<5$ yrs tenure & $\begin{array}{c}-1.186 \\
(0.133)^{* *}\end{array}$ & $\begin{array}{c}0.625 \\
(0.189)^{* *}\end{array}$ & $\begin{array}{c}-1.378 \\
(0.235)^{* *}\end{array}$ & $\begin{array}{c}0.368 \\
(0.281)\end{array}$ & & \\
\hline $\operatorname{mfp}$ & $\begin{array}{c}-0.147 \\
(0.016)^{* *}\end{array}$ & $\begin{array}{c}0.05 \\
(0.022)^{*}\end{array}$ & $\begin{array}{c}-0.169 \\
(0.026)^{* *}\end{array}$ & $\begin{array}{c}0.052 \\
(0.031)\end{array}$ & $\begin{array}{c}-0.104 \\
(0.026)^{* *}\end{array}$ & $\begin{array}{c}0.027 \\
(0.024)\end{array}$ \\
\hline professional/technical & $\begin{array}{c}-0.756 \\
(0.172)^{* *}\end{array}$ & $\begin{array}{c}0.526 \\
(0.243)^{*}\end{array}$ & $\begin{array}{c}-0.729 \\
(0.307)^{*}\end{array}$ & $\begin{array}{c}0.21 \\
(0.367)\end{array}$ & $\begin{array}{l}-0.035 \\
(0.261)\end{array}$ & $\begin{array}{c}0.146 \\
(0.242)\end{array}$ \\
\hline
\end{tabular}




\begin{tabular}{|c|c|c|c|c|c|c|}
\hline union & $\begin{array}{c}0.364 \\
(0.089)^{* *}\end{array}$ & $\begin{array}{c}0.259 \\
(0.126)^{*}\end{array}$ & $\begin{array}{c}0.374 \\
(0.134)^{* *}\end{array}$ & $\begin{array}{l}0.161 \\
(0.16)\end{array}$ & $\begin{array}{c}0.453 \\
(0.152)^{* *}\end{array}$ & $\begin{array}{c}0.212 \\
(0.141)\end{array}$ \\
\hline firm size $>=100$ & $\begin{array}{c}0.053 \\
(0.103)\end{array}$ & $\begin{array}{l}-0.064 \\
(0.146)\end{array}$ & $\begin{array}{l}0.289 \\
(0.21)\end{array}$ & $\begin{array}{l}-0.069 \\
(0.251)\end{array}$ & $\begin{array}{c}0.13 \\
(0.178)\end{array}$ & $\begin{array}{l}-0.105 \\
(0.165)\end{array}$ \\
\hline return to capital & $\begin{array}{l}-0.006 \\
(0.01)\end{array}$ & $\begin{array}{c}0.006 \\
(0.014)\end{array}$ & $\begin{array}{c}0.001 \\
(0.017)\end{array}$ & $\begin{array}{l}-0.007 \\
(0.02)\end{array}$ & $\begin{array}{l}-0.017 \\
(0.017)\end{array}$ & $\begin{array}{c}0.012 \\
(0.015)\end{array}$ \\
\hline part-time & $\begin{array}{c}0.986 \\
(0.184)^{* *}\end{array}$ & $\begin{array}{c}-0.689 \\
(0.260)^{* *}\end{array}$ & $\begin{array}{c}1.399 \\
(0.350)^{* *}\end{array}$ & $\begin{array}{l}-0.528 \\
(0.419)\end{array}$ & $\begin{array}{c}0.596 \\
(0.308)\end{array}$ & $\begin{array}{c}-0.483 \\
(0.285)\end{array}$ \\
\hline weekly wage & $\begin{array}{c}0.085 \\
(0.073)\end{array}$ & $\begin{array}{c}-0.041 \\
(0.104)\end{array}$ & $\begin{array}{c}0.194 \\
(0.131)\end{array}$ & $\begin{array}{l}-0.043 \\
(0.157)\end{array}$ & $\begin{array}{l}-0.091 \\
(0.122)\end{array}$ & $\begin{array}{c}0.052 \\
(0.113)\end{array}$ \\
\hline employment share & $\begin{array}{l}1.168 \\
(0.97)\end{array}$ & $\begin{array}{c}-1.815 \\
(1.372)\end{array}$ & $\begin{array}{c}2.55 \\
(1.664)\end{array}$ & $\begin{array}{c}-0.721 \\
(1.992)\end{array}$ & $\begin{array}{c}-1.05 \\
(1.617)\end{array}$ & $\begin{array}{c}-0.646 \\
(1.496)\end{array}$ \\
\hline health insurance & $\begin{array}{c}-0.825 \\
(0.179)^{* *}\end{array}$ & $\begin{array}{c}0.347 \\
(0.253)\end{array}$ & $\begin{array}{c}-1.325 \\
(0.349)^{* *}\end{array}$ & $\begin{array}{c}0.085 \\
(0.418)\end{array}$ & $\begin{array}{c}0.056 \\
(0.256)\end{array}$ & $\begin{array}{c}-0.117 \\
(0.237)\end{array}$ \\
\hline cash balance plans & $\begin{array}{c}-0.016 \\
(0.056)\end{array}$ & $\begin{array}{c}0.237 \\
(0.080)^{* *}\end{array}$ & $\begin{array}{l}-0.085 \\
(0.108)\end{array}$ & $\begin{array}{c}0.348 \\
(0.129)^{* *}\end{array}$ & $\begin{array}{c}0.013 \\
(0.097)\end{array}$ & $\begin{array}{c}0.221 \\
(0.090)^{*}\end{array}$ \\
\hline cash balance participants & $\begin{array}{c}2.609 \\
(1.588)\end{array}$ & $\begin{array}{c}4.344 \\
(2.246)\end{array}$ & $\begin{array}{c}7.746 \\
(3.642)^{*}\end{array}$ & $\begin{array}{c}5.994 \\
(0.358)\end{array}$ & $\begin{array}{c}3.32 \\
(2.737)\end{array}$ & $\begin{array}{c}3.969 \\
(2.533)\end{array}$ \\
\hline Constant & $\begin{array}{c}-0.256 \\
(0.036)^{* *}\end{array}$ & $\begin{array}{c}0.284 \\
(0.051)^{* *}\end{array}$ & $\begin{array}{c}-0.367 \\
(0.074)^{* *}\end{array}$ & $\begin{array}{c}0.249 \\
(0.088)^{* *}\end{array}$ & $\begin{array}{l}-0.093 \\
(0.054)\end{array}$ & $\begin{array}{c}0.198 \\
(0.050)^{* *}\end{array}$ \\
\hline $\begin{array}{l}\text { Test of joint significance } \\
\text { of } 8 \text { region dummy } \\
\text { variables (p-value) }\end{array}$ & $\begin{array}{l}145.79 \\
(0.00)\end{array}$ & $\begin{array}{l}42.72 \\
(0.00)\end{array}$ & $\begin{array}{l}56.93 \\
(0.00)\end{array}$ & $\begin{array}{l}28.48 \\
(0.00)\end{array}$ & $\begin{array}{l}43.25 \\
(0.00)\end{array}$ & $\begin{array}{l}30.05 \\
(0.00)\end{array}$ \\
\hline R-Square & 0.98 & 0.92 & & & 0.93 & 0.90 \\
\hline Observations & 40 & 40 & 40 & 40 & 40 & 40 \\
\hline
\end{tabular}

Standard errors are shown in parentheses. * significant at 5\% ** significant at $10 \%$ 
Figure 1 - Pension Participation 1979-1998

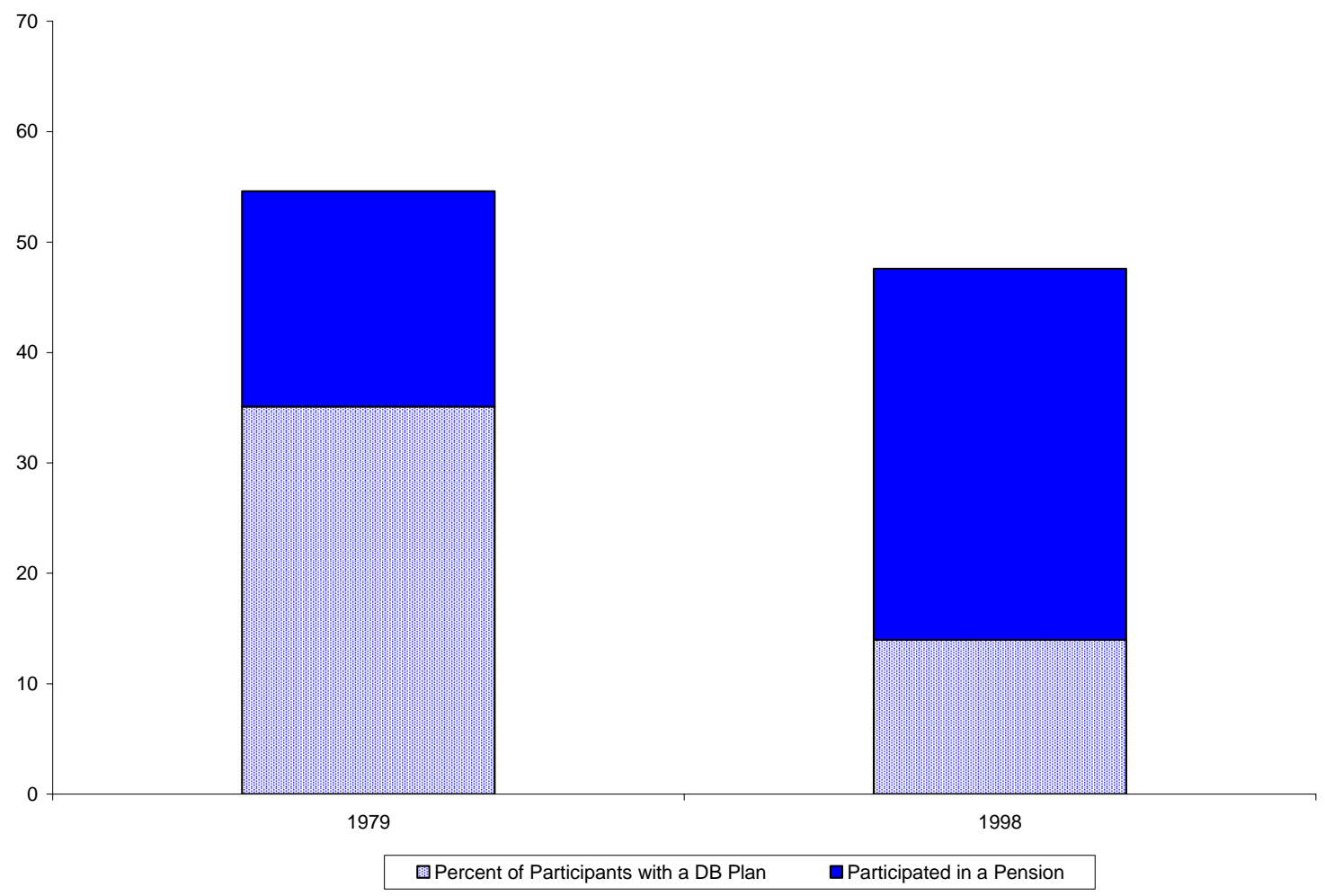


Figure 2 - Contributions of Economic Conditions to Rates of Decline in DB Coverage*

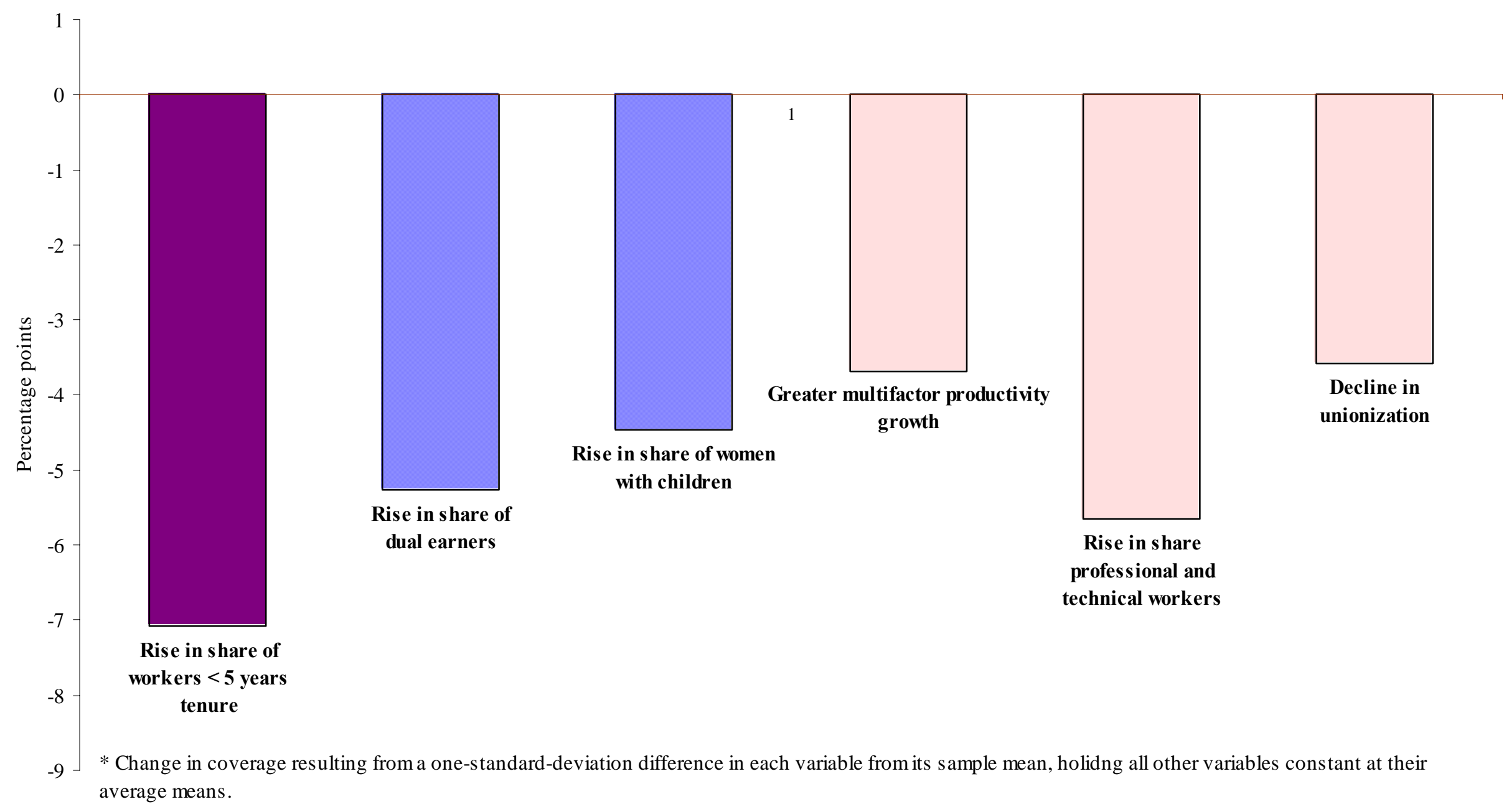


Figure 3 - Contributions of Economic Conditions to Rates of Increase in DC Coverage*

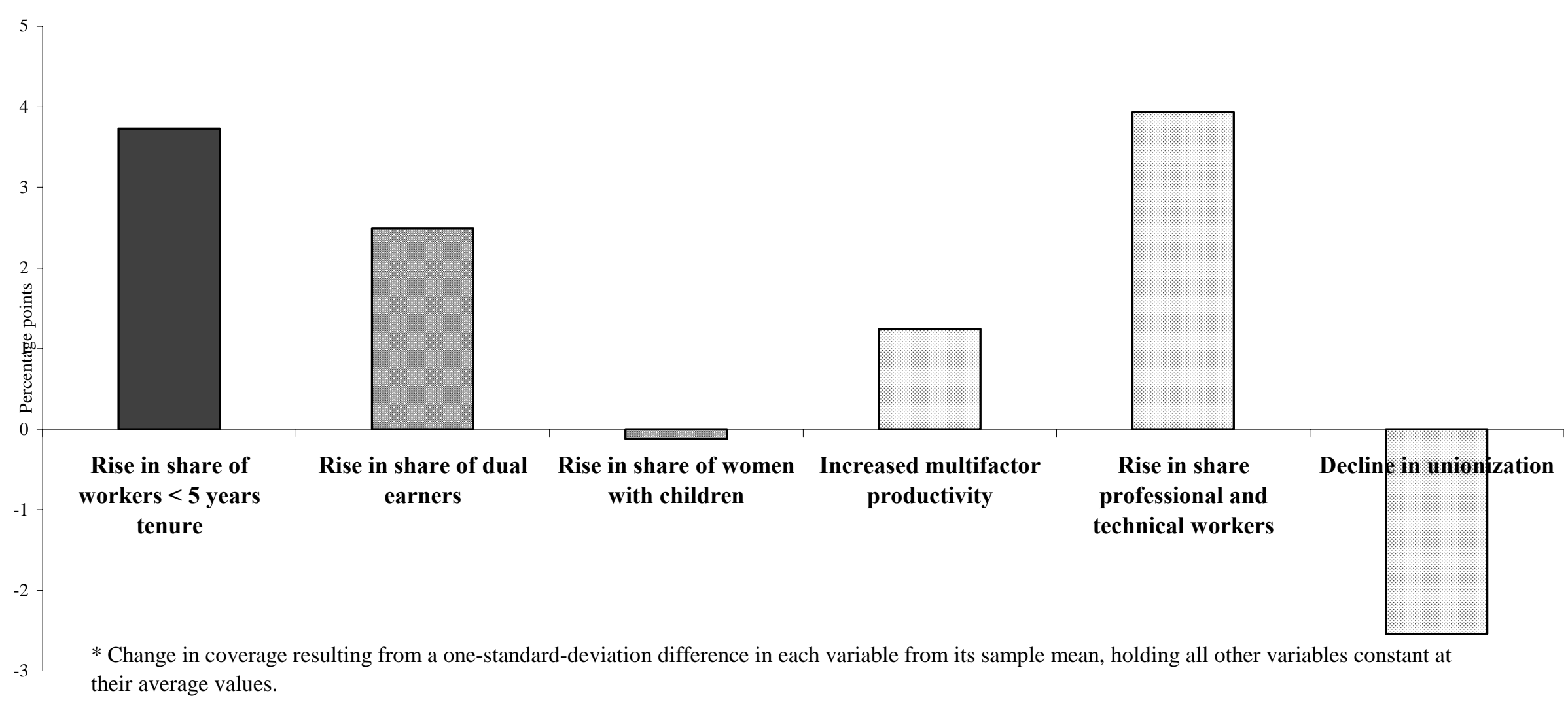


